\title{
Hubungan Antara Regulasi Diri dan Perencanaan Karir pada Remaja Putri Bali
}

\author{
Ni Luh Arick Istriyanti dan Nicholas Simarmata \\ Program Studi Psikologi, Fakultas Kedokteran, Universitas Udayana \\ arick.istriyanti@gmail.com
}

\begin{abstract}
Abstrak
Salah satu tugas perkembangan remaja yaitu terlibat dalam peran sosial dan dapat melakukan persiapan karir dengan melakukan perencanaan karir yang tepat. Ketika remaja dihadapkan pada budaya yang mengikat, seperti remaja putri Bali yang tergabung dalam organisasi sekaa teruna, mereka dituntut untuk terlibat dalam setiap kegiatan budaya sebagai bagian dari peran sosial, sekaligus melakukan perencanaan karir sebagai persiapan masa depan mereka. Dalam melakukan perencanaan karir, remaja memerlukan kemampuan untuk dapat mengelola potensi dan informasi yang mereka peroleh tanpa mengabaikan peran sosialnya. Maka dari itu, remaja putri Bali memerlukan cara yang tepat untuk dapat melakukan perencanaan karir dan melaksanakan peran sosialnya, yaitu dengan memiliki regulasi diri yang baik. Oleh karena itu, peneliti berasumsi bahwa ada hubungan positif antara regulasi diri dengan perencanaan karir remaja putri Bali.

Metode penelitian ini yaitu korelasi kuantitatif, dimana jumlah subjeknya 135 remaja putri Bali yang tergabung dalam organisasi sekaa teruna di Kabupaten Badung dan usianya 15-20 tahun. Metode pengumpulan datanya yaitu skala regulasi diri dan skala perencanaan karir. Reliabilitas regulasi diri sebesar 0,916 dan reliabilitas perencanaan karir sebesar 0,911. Normalitas variabel regulasi diri sebesar 0,098 dan normalitas variabel perencanaan karir sebesar 0,269. Linieritas antara variabel regulasi diri dan perencanaan karir yaitu 0,000. Koefisien determinasinya (r2) 0,354 . Metode analisis datanya yaitu teknik korelasi product moment dari Pearson.. Koefisien korelasinya 0,595 dengan probabilitas 0,000. Hal tersebut membuktikan bahwa ada hubungan positif antara regulasi diri dan perencanaan karir pada remaja putri Bali.
\end{abstract}

Kata kunci: Regulasi diri, perencanaan karir, remaja putri Bali

\begin{abstract}
Adolescences have many developmental tasks. Some of them are getting involved into social role and capable of doing a proper career planning. When adolescences are faced by the strict culture, like Balinese Teenage Girls who involved into sekaa teruna organization, they have to actively participate in every cultural activity as a part of social role, and also doing career planning for their future's preparation. In doing career planning, adolescences need the ability to manage their potential and retrieved information without ignoring their social roles. Therefore, Balinese Teenage Girls need to find the right way to do career planning and fulfill their social roles that are have a good self-regulation. Because of that researcher assumed that there is a positive relationship between self-regulation and career planning of Balinese Teenage Girls.

This research method is quantitative-correlation, using 135 subjects that are Balinese Teenage Girls who joined sekaa teruna organization in Badung and their age ranges from 15-20 years old. Method used for collecting the data is questionnaire which is self-regulation scale and career planning scale. The reliability of self-regulation variable is 0.916 and for the career planning variable is 0.911 . The normality of self-regulation variable is 0.098 and for the career planning variable is 0.269 . The linearity between self-regulation variable and career planning variable is 0.000 . The determination coefficient is 0.354 . The analysis method is Pearson product moment correlation techniques. The correlation coefficient is 0.595 with 0.000 probabilities. It is proved there is a positive relationship between selfregulation and career planning of Balinese Teenage Girls.
\end{abstract}

Keywords: Self-Regulation, Career Planning, Balinese Teenage Girls 


\section{LATAR BELAKANG}

Masa remaja merupakan masa yang paling menyenangkan akan tetapi sekaligus menjadi masa yang paling membingungkan. Dikatakan menyenangkan, karena pada masa ini seseorang mulai memikirkan tentang cita-cita, harapan dan keinginan- keinginannya. Namun juga masa yang membingungkan, karena ia mulai menyadari masalah-masalah yang muncul ketika ia mencoba untuk mengintegrasikan antara keinginan diri dengan keinginan orang-orang di sekitarnya (Beuder, 2007). Hurlock (dalam Romera, 2001), menyatakan bahwa remaja pada dasarnya merupakan masa transisi antara masa kanak-kanak dan masa dewasa yang disertai dengan beberapa perubahan penting dalam hidupnya seperti perubahan fisik, psikologis, mental dan sosial. Dalam setiap tahapan perubahan inilah seorang remaja akan banyak dihadapkan dengan pilihan- pilihan yang membingungkan sampai pada penentuan keputusan yang tepat untuk dirinya.

Seiring dengan perubahan-perubahan yang dialami, seorang remaja akan dihadapkan pada penambahan tugas dalam kehidupannya. Tugas tersebut berupa tugas perkembangan remaja. Menurut Sarwono (2011) tugas perkembangan yang dimiliki oleh remaja adalah salah satu cara untuk membuktikan keberadaanya dalam lingkungan sosial. Hurlock (2001) merumuskan terdapat beberapa tugas perkembangan yang seharusnya dapat dilakukan oleh remaja, yaitu menerima keadaan fisiknya dan menggunakan tubuhnya secara efektif, dapat mencapai peran dan keterlibatan dalam lingkungan sosialnya, mencapai hubungan interpersonal dengan orang-orang disekitarnya, mencapai kemandirian emosional dari orang tua dan orang-orang dewasa lainnya serta dapat melakukan persiapan karir yang tepat untuk masa depan kehidupannya. Maka dari itu, menjadi hal yang penting bagi remaja untuk dapat menjalankan setiap tugas perkembangannya dengan tepat sebagai bagian dari eksistensinya.

Dalam melaksanakan tugas perkembangan, remaja dituntut untuk dapat berperan dalam lingkungan sosial (Santrock, 2007). Dari pernyataan tersebut, secara tidak langsung menjadikan remaja sudah mulai memiliki tanggung jawab terhadap dirinya. Budaya yang berbeda dapat melahirkan proses kehidupan sosial yang berbeda dan melahirkan peranan sosial yang berbeda pula bagi remaja itu sendiri (Sarwono, 2011). Budaya yang kental biasanya akan lebih banyak memerlukan peran dari anggota kebudayaan tersebut yang dikenal sebagai bagian dari peran sosial (Matsumoto, 2008). Seligman (2001) menyatakan bahwa budaya yang kental akan dapat mempengaruhi seorang remaja untuk mengambil keputusan khususnya dalam menentukan pilihan karir, dimana keputusan tersebut dapat memiliki dampak yang positif dan negatif yang sangat tergantung dari pengaturan diri dan dukungan orang-orang terdekatnya.
Salah satu peran sosial dari para remaja dalam suatu budaya dapat kita lihat dari remaja putri Bali yang sudah tergabung dalam sebuah organisasi kepemudaan yang disebut dengan sekaa teruna. Sekaa teruna merupakan organisasi kepemudaan yang ada di Bali, dimana anggotanya merupakan remaja putra dan remaja putri. Peraturan dalam sekaa teruna diatur dalam peraturan adat yang disebut awig- awig (Utama, 2009). Tergabung dalam organisasi sekaa teruna merupakan tahapan awal untuk menjadi bagian dari kebudayaan masyarakat Bali. Keterlibatan remaja putri Bali dalam kegiatan budaya dan adat bertujuan agar mereka mulai mempelajari adat yang ada untuk kehidupan kedepannya nanti dalam rangka mempertahankan adat dan budaya setempat (Werdhi, 2009). Keteraturan sebagai seorang remaja dalam budaya yang kental sangat diperlukan untuk memantapkan remaja ketika menentukan pilihan-pilihan dalam hidupnya (Leong dalam Santrock, 2007). Beranekaragamnya kegiatan adat dan budaya yang terdapat di Bali menjadikan remaja putri Bali yang tugasnya lebih banyak dibandingkan remaja putra, hendaknya dapat memiliki keteraturan diri yang baik. Hal ini bertujuan agar remaja putri Bali tidak hanya fokus pada satu tugas saja, namun dapat melakukan tugas- tugas yang lain seperti kehidupannya bersama teman sebaya, lingkungan sosial budaya dan menentukan masa depan yang erat kaitannya dengan persiapan karir. Terlebih Bali yang menganut sistem patriarki menjadikan remaja putri harus benar-benar memantapkan diri, baik dalam perannya sebagai bagian dari kegiatan budaya, dan dalam penentuan masa depan seperti melakukan pilihan terhadap karir yang ia inginkan (Raditya, 2011), sehingga nantinya ketika berada ditempat suami dalam budaya keluarga dan lingkungan yang berbeda akan dapat menjalankan fungsinya dengan optimal.

Persiapan karir merupakan sesuatu yang tidak banyak dilakukan oleh masyarakat Bali (Raditya, 2011). Hal tersebut terjadi salah satunya karena pemahaman masyarakat tentang karir hanya sebatas pada pekerjaan yang akan mereka dapatkan tanpa adanya pengembangan terhadap pekerjaannya (Wiranatha, 2005). Pemerataan dalam berkarir juga menjadi masalah bagi masyarakat Bali, dimana jika dilihat dari bidang ekonomi posisi perempuan Bali dari tahun ke tahun ada pada posisi yang jauh lebih rendah dibandingkan dengan laki- laki (Astiti, 2008). Berdasarkan data BPS provinsi Bali dalam tingkat pastisipasi angkatan kerja tahun 2007 mencapai $58,78 \%$ dan tahun 2008 terjadi peningkatan dengan persentase mencapai $62,74 \%$. Sedangkan laki-laki mencapai $80,97 \%$ dan $90,11 \%$. Jumlah ini mengindikasikan bahwa perempuan masih ketinggalan dalam berpartisipasi pada kegiatan-kegiatan ekonomi. Kondisi tersebut menurut Astiti (2008) akan terus dapat terjadi jika perempuan Bali tidak mempetakan diri untuk merancang masa depan terkait dengan kehidupan ekonomi mereka. Keputusan untuk tidak melakukan perencanaan dalam rangka mempersiapkan masa depan sangat dipengaruhi oleh 
pengalaman individu, sosial budaya yang mempengaruhi sruktur maupun peluang yang tersedia (Tracey dalam Santrock 2007). Pernyataan tersebut sangat sesuai dengan keadaan yang dinyatakan oleh Windiana (2010), bahwa seorang wanita Bali yang memiliki peran yang lebih besar dalam urusan adat dan rumah tangga terutama bagi wanita Bali yang tinggal di desa, biasanya tidak banyak terlibat dalam karir dan tidak banyak memanfaatkan peluang terkait dengan kemajuan masa depan mereka. Keadaan inilah yang nantinya dapat dijadikan pengalaman bagi remaja putri Bali jika mereka tidak diberikan pemahaman yang tepat terkait dengan pentingnya masa depan mereka .

Ditengah keterlibatan remaja putri Bali dalam budaya, terdapat beberapa permasalahan yang membuat mereka melupakan persiapan karirnya. Salah satunya ditunjukkan dengan keputusan remaja untuk menikah terlebih dahulu tanpa memikirkan sumber penghasilan yang akan mereka peroleh (Arjani, 2007). Pernyataan tersebut didukung dengan adanya data dari BPS kabupaten Badung tahun 2010 nampak bahwa persentase perkawinan perempuan di bawah umur, yakni usia 10-16 tahun masih relatif tinggi yakni mencapai 5,79\%, usia 17-18 tahun mencapai $14,15 \%$, jumlah ini mengalami kenaikan dari tahun ke tahun (BPS, 2010). Menurut Arjani (2007) pernikahan dini yang terjadi pada remaja, khususnya pada remaja putri biasanya diikuti dengan predikat rumah tangga miskin. Kondisi tersebut dapat disebabkan belum adanya persiapan yang matang terhadap kebutuhan finansial (Arjani, 2007). Selain itu rendahnya pendidikan juga dapat berkontribusi terhadap keadaan tersebut. Berdasarkan angka buta huruf pada perempuan diwilayah Badung mencapai 12,78\%, sedangkan pada laki-laki hanya $2,57 \%$. Keadaan tersebut juga diikuti dengan lebih rendahnya tingkat partisipasi sekolah pada perempuan dibandingkan dengan laki-laki di kabupaten Badung (BPS, 2010). Maka dari itu Bali dengan adatnya yang cukup mengikat, semestinya dapat menumbuhkan budaya untuk memiliki konsep masa depan yang matang bagi para remaja Bali (Arjani, 2007). Dari hasil diskusi dengan beberapa remaja Bali yang sudah mulai terlibat dalam organisasi adat, juga terdapat kecenderungan bahwa mereka akan memilih pekerjaan yang bisa membuat mereka aman dalam kegiatan adat terlebih jika mereka menikah di tempat yang nuansa adatnya cukup kental dan jika tidak menemukan pekerjaan, biar waktu yang menentukan (Raditya, 2011) .

Selain menjalankan peran sosial, menjadi tugas yang penting bagi remaja dalam menentukan perencanaan karir untuk persiapan karir yang lebih baik. Tujuannya agar tidak terjadi ketergantungan ketika akan menjalani tahapan kehidupan yang lebih tinggi (Hurlock, 2001). Selain itu, perencanaan karir yang sedini mungkin akan memudahkan seseorang untuk memperhitungkan karir yang akan mereka inginkan (Beuder, 2007). Sebuah perencanaan karir yang dilakukan sejak dini akan membuat remaja lebih siap, sehingga nantinya dapat melaksanakan setiap tugas perkembangannya dengan tepat sampai akhirnya mereka memutuskan untuk menikah dan membangun rumah tangga dengan memiliki kesiapan baik dari segi mental dan finansial (Santrock, 2007)

Memang tidak mudah bagi remaja dalam masa transisi dengan menghadapi beberapa perubahan untuk dapat menyeimbangkan tuntutan dari lingkungan sosial. Hal ini dapat dilihat dari peran remaja putri Bali yang terlibat kegiatan budaya dan adat, namun disisi lain harus menjalankan tugas untuk kehidupan yang lebih baik dengan mempersiapkan karir melalui perencanaan karir yang matang. Terlebih remaja masih sering berada pada kondisi atau suasana hati yang labil akan mempermudah mereka untuk mengalami permasalahan yang dapat mengganggu tugas perkembangannya (Apranadyanti, 2010). Oleh sebab itu regulasi diri atau pengaturan diri menjadi hal yang perlu diperhatikan dalam menjalankan tugas perkembangan sebagai seorang remaja, baik itu berupa kewajibannya untuk menjalankan tugas- tugas dalam lingkup kebudayaan yang cukup mengikat dan mengatur pengalaman yang diperoleh dari lingkungan khususnya dalam melakukan perencanaan untuk persiapan karir.

Bandura (dalam George, 2004) menyatakan, regulasi diri merupakan kemampuan untuk mengontrol perilaku sendiri dan salah satu dari sekian penggerak utama kepribadian manusia yang terdiri dari pengamatan, penilaian dan respon diri. Regulasi diri merupakan faktor internal yang ada pada diri individu (Apranadyanti, 2010). Faktor internal inilah yang harus dimiliki remaja putri Bali dalam mengatur perannya sebagai seorang remaja berupa keterlibatannya sebagai anggota masyarakat adat serta dalam menentukan karir yang lebih baik untuk masa depannya. Menurut Taylor (2009) melalui regulasi diri seseorang dengan mudah akan menemukan gambaran masa depannya sehingga sangat penting untuk dapat mengembangkan keterampilan dalam melakukan regulasi diri pada setiap tugas yang melibatkan pemahaman diri serta kaitannya dengan keadaan diluar diri. Regulasi diri terdapat dalam setiap individu akan tetapi tidak semua individu dapat memanfaatkan hal tersebut pada situasi yang tepat, oleh karena itu regulasi diri perlu dilatih sehingga dapat menentukan pilihan- pilihan dalam hidup (Taylor, 2009). Dalam memperoleh pilihan karir yang tepat seseorang harus dapat melakukan perencanaan yang tepat, yang erat kaitannya dengan pengaturan diri dan informasi yang diperoleh (Parsons dalam Winkel \& Hastuti, 2007). Maka dari itu perencanaan karir yang tepat berasal dari pengaturan diri dan lingkungan yang tepat pula.

Berdasarkan pernyataan diatas, tujuan dari penelitian ini adalah ingin mengetahui hubungan antara regulasi diri dan perencanaan karir pada remaja putri Bali yang terlibat dalam 
organisasi kepemudaan serta dapat mengetahui sumbangan regulasi diri terhadap perencanaan karir pada remaja putri Bali yang terlibat dalam organisasi sekaa teruna yang merupakan bagian dari peran sosialnya.

\section{METODE}

\section{Variabel dan definisi operasional}

Menurut Direktorat Pendidikan Tinggi Depdikbud (Narbuko \& Achmadi, 2004) menjelaskan bahwa, yang dimaksud dengan variabel penelitian adalah segala sesuatu yang akan menjadi objek pengamatan penelitian. Terdapat dua jenis variabel dalam penelitian ini yakni variabel bebas dan variabel tergantung.

Variabel bebas adalah variabel yang mempengaruhi atau yang menjadi sebab perubahan dari variabel tergantung. Variabel ini sering disebut variabel stimulus, predictor, anteceden (Sugiyono, 2009). Variabel bebas dalam penelitian ini adalah regulasi diri.

Variabel tergantung merupakan variabel yang dipengaruhi atau yang menjadi akibat, karena adanya variabel bebas. Variabel ini sering disebut sebagai variabel output, kriteria, konsekuen (Sugiyono, 2009). Variabel tergantung dari penelitian ini adalah perencanaan karir.

Definisi operasional adalah suatu definisi mengenai variabel yang dirumuskan berdasarkan karakteristikkarakteristik variabel tersebut yang dapat diamati (Azwar, 2010).

Adapun definisi operasional dari variabel- variabel penelitian ini, sebagai berikut:

1. Regulasi diri, adalah kemampuan seseorang dalam mengatur perilaku dan emosi yang didalamnya melibatkan proses pemahaman perencanaan, penilaian, penerapan terkait dengan perubahan yang diinginkan dalam mencapai suatu tujuan untuk dapat diterima di lingkungan sosialnya dimana indikatornya yakni penerimaan informasi yang relevan, mengevaluasi informasi yang diperoleh, membuat suatu perubahan dari evaluasi yang sudah dilakukan, mencari solusi terkait dengan melaksanakan peran sosial dan dalam persiapan karir, merancang suatu rencana, penerapan rencana dan pengukuran efektivitas dari rencana yamg diukur dengan menggunakan skala regulasi diri.

2. Perencanaan karir, adalah kemampuan seseorang untuk mengidentifikasi tujuan yang didalamnya melibatkan proses yang berkelanjutan berupa perencanaan, pemahaman diri, penilaian kerja serta adanya pemahaman rasional terhadap tujuan yang ingin dicapai dimana indikatornya yakni pengetahuan dan pemahaman diri sendiri, pengetahuan dan pemahaman dunia kerja, penalaran yang realistis akan hubungan pengetahuan serta pemahaman diri sendiri dengan pengetahuan dan pemahaman dunia kerja yang diukur dengan skala perencanaan karir.

\section{Responden}

Dalam penelitian ini responden dipilih dengan menggunakan teknik cluster random sampling dari populasi remaja Putri Bali di Provinsi Bali. Responden penelitian berjumlah 135 remaja putri Bali. Penelitian ini menggunakan remaja yang berusia 15 - 20 tahun, karena dalam usia ini (15 tahun) yang merupakan akhir dari remaja awal dan (20 tahun) akhir dari remaja akhir. Menurut Hurlock (2000), pada masa ini seseorang remaja sudah menghadapi dan berdaptasi terhadap perubahan yang ada pada dirinya baik itu perubahan fisik, perubahan pikologis dan mental serta perubahan sosial terkait dengan keterlibatannya dalam peran sosial. Selain itu juga, dalam teori Gizberg ketika memasuki usia 15 tahun seorang remaja sudah ada pada tahap tentative yang berarti remaja sudah mulai mengevaluasi minat terhadap pilihanpilihan karir yang mereka inginkan. Sedangkan memasuki usia 20 tahun, remaja sudah mempersiapkan diri untuk memilih pekerjaan spesifik terhadap karir yang sudah ditentukan sebelumnya (Santrock, 2007). Remaja dalam rentang usia 14 sampai 20 tahun semestinya sudah mulai mempersiapkan karir mereka sehingga akan mempermudah diri untuk melakukan pilihan karir yang diinginkan (Hurlock, 2000). Responden juga merupakan remaja putri Bali yang sudah tergabung dalam organisasi kepemudaan, tujuannya agar memperoleh seorang remaja putri yang sudah terlibat dalam kehidupan sosial dan memiliki peran sosial sebagai salah satu bagian dari tugas perkembangan remaja. Keikutsertaan dalam organisasi juga menjadi pertimbangan, yakni minimal satu tahun, dikarenakan remaja sudah mulai memiliki pengalaman dalam mengikuti kegiatan adat jika tergabung dalam sekaa teruna. Selain itu, diharapkan dapat mengetahui regulasi dirinya ketika sudah terlibat dalam kegiatan sosial dan adat serta ketika harus menjalankan tugas perkembangan remaja lainnya.

Organisasi sekaa teruna diatur oleh dua aturan adat yakni awig- awig dan pararem (Windia, 2011). Dalam awigawig terdapat aturan keanggotaan sekaa teruna, yakni dengan syarat usia minimal 15 tahun yang juga menjadi pertimbangan peneliti untuk memilih rentang usia 15- 20 tahun. Keanggoataan dalam organisasi sekaa teruna juga dilihat dari keanggotaan keluarga dalam desa adat dan dinas. Apabila keluarga merupakan anggota desa adat dan dinas berarti anaknya yang sudah memasuki usia remaja diwajibkan untuk masuk dalam organisasi sekaa teruna (Utama, 2009). Seorang remaja yang sudah tergabung dalam sekaa teruna memiliki kewajiban untuk terlibat dalam kegiatan adat dan dapat menggantikan orang tua mereka dalam kegiatan adat jika orang tua mereka sedang sakit atau bekerja ke luar daerah (Utama, 2009). 


\section{Tempat Penelitian}

Penelitian ini diadakan di 4 organisasi sekaa teruna di Kabupaten Badung pada bulan Desember 2012 sampai dengan bulan Januari 2013

\section{Alat ukur}

Alat ukur yang digunakan dalam penelitian ini adalah kuesioner. Terdapat dua kuesioner yang digunakan yakni kuesioner regulasi diri dan kuesioner perencanaan karir. Kuesioner regulasi diri diadaptasi dan dimodifikasi sesuai dengan tujuan penelitian dari Self Regulation Questionnaire Miller \& Brown (1991). Sedangkan kuesioner perencanaan karir dibuat sendiri oleh peneliti berdasarkan aspek-aspek perencanaan karir yang dikemukakan oleh Parson (2006). Item- item dalam kuesioner ini menggunakan pilihan jawaban secara skala interval. Setiap kuesioner memiliki empat pilihan jawaban untuk mengukur persetujuan pada pernyataan dalam kuesioner yakni, sangat setuju, setuju, tidak setuju dan sangat tidak setuju.

Sebelum kuesioner diberikan kepada responden penelitian, terlebih dahulu dilakukan uji coba alat ukur penelitian kepada 60 orang remaja Putri Bali dengan karakteritik responden yang sudah disampikan diatas. Tujuan dilakukan uji coba penelitian adalah untuk mengetahui validitas dan reliabilitas. Penelitian ini meninjau validitas konstruk dan validitas isi, sedangkan reliabilitas diuji dengan pendekatan konsistensi internal. Validitas konstruk diuji dengan mengetahui nilai rix pada batas toleransi 0,30 dan untuk validitas isi menggunakan teknik professional judgement, dengan memberikan kepada dosen pembimbing skripsi untuk mengetahui keabsahan pada setiap item kuesioner. Pengujian reliabilitas dilakukan dengan menggunakan teknik cronbach's alpha melalui program SPSS 17.

Melalui pengujian validitas dan relibilitas dapat diketahui kuesioner regulasi diri memiliki 42 item yang valid dari 63 item yang diuji dengan koefisien reliabilitas sebesar 0,916. Sedangkan koesioner perencanaan karir terdapat 29 item yang valid dari 30 item diuji dengan koefisien relibilitas sebesar 0,911 .

\section{Metode pengumpulan data}

Metode pengumpulan data merupakan cara mengumpulkan data dalam penelitian dan untuk mengumpulkan data diperlukan sebuah alat. Penelitian ini melakukan pengukuran terhadap dua variabel penelitian yakni variabel regulasi diri dan variabel perencanaan karir. Kedua variabel diukur dengan menggunkan kuesioner yang berisikan daftar pertanyaan yang telah disiapkan dan disusun sedemikian rupa, sehingga calon responden tinggal memilih salah satu jawaban yang tersedia. Metode pengumpulan data menggunakan alat ukur berupa kuesioner karena data yang ingin diukur berupa konstruk atau konsep psikologis yang dapat diungkap secara tidak langsung melalui indikatorindikator perilaku dalam bentuk item- item pernyataan (Azwar, 2000). Pengumpulan data dilakukan dengan menyebarkan kuesioner penelitian kepada responden melalui teknik cluster random sampling dari populasi remaja putri Bali di provinsi Bali. Sebelum menyebarkan kuesioner ke beberapa organisasi sekaa teruna, peneliti melalukan permohonan ijin untuk mendapatkan persetujuan melakukan pengambilan data pada organisasi yang dituju. Akhirnya diperoleh 4 organisasi sekaa teruna yang memberikan ijin untuk proses pengambilan data penelitian. Setelah itu seluruh data yang diperoleh diolah dengan menggunakan program SPSS 17.

\section{Teknik analisis data}

Jenis penelitian ini merupakan studi korelasional, sehingga setelah data keseluruhan diperoleh melalui penyebaran kuisioner regulasi diri dan perencanaan karir maka selanjutnya seluruh data akan dianalisa. Teknik analisa data yang digunakan adalah analisis korelasi Product Moment Pearson, dengan pendekatan one tailed karena hanya terdapat satu variabel bebas yakni regulasi diri dan satu variabel tergantung berupa perencanaan karir serta hasil analisis korelasinya langsung menunjukkan arah.

Analisis akan dilanjutkan dengan melihat koefisien determinan yang bertujuan untuk mengetahui sumbangan dari variabel regulasi diri terhadap variabel perencanaan karir. Analisis data keseluruhan akan dilakukan dengan program komputasi SPSS for Windows Release 17.0.

\section{Hasil Penelitian}

Menurut Sugiyono (2009) teknik analisa data dengan menggunakan product moment dapat digunakan apabila data memenuhi kriteria yakni memiliki sebaran data normal dan linier. Maka dari itu sebelum mengetahui hubungan antar variabel yang diteliti, peneliti melakukan uji asumsi meliputi uji normalitas dan uji linieritas.

Uji normalitas dilakukan dengan menggunakan Kolmogorov-Smirnov melalui program SPSS 17. Data dikatakan memiliki distribusi normal apabila hasil uji normalitasnya lebih besar dari taraf signifikansi 0,05. Hasil pengujian dapat dilihat pada tabel berikut :

Tabel 1

Hasil Uji Normalitas

\begin{tabular}{ccc}
\hline & Regulasi Diri & Perencanaan Karir \\
\hline Kolmogorov-Smirnov Z & 1.228 & 1.001 \\
Asymp. Significant & 0.098 & 0.269 \\
\hline
\end{tabular}


Pada tabel diatas dapat diketahui sebaran data pada variabel regulasi diri memiliki nilai signifikansi dengan probabilitas (p) 0,098 atau mempunyai probalilitas di atas 0,05 ( $p>0,05$ ). Sedangkan sebaran data pada variabel perencanaan karir memiliki nilai signifikansi dengan probabilitas (p) 0,269 atau mempunyai probalilitas di atas 0,05 ( $\mathrm{p}>0,05)$. Hal ini menunjukkan bahwa sebaran data pada kedua variabel bersifat normal.

Selanjutnya dilakukan uji linieritas untuk mengetahui variabel regulasi diri dan variabel perencanaan karir dapat berkorelasi secara linier. Apabila nilai probabilitasnya berada di bawah taraf signifikansi 0,05, maka hubungan kedua variabel linear. Berikut hasil uji linieritas:

$$
\text { Tabel } 2
$$

Hasil Uji Linearitas

\begin{tabular}{ccccc}
\hline & & & $F$ & Signifikansi \\
\hline perencanaanka & Between & (Combined) & 2.934 & .000 \\
rir * & Groups & Linearity & 75.565 & .000 \\
regulasidiri & & Deviation from & 1.119 & .324 \\
& & Linearity & & \\
\hline
\end{tabular}

Hasil pengujian dengan uji linearitas menunjukkan bahwa hubungan kedua variabel adalah linear karena memiliki probabilitas (p) sebesar 0,000 atau memiliki taraf signifikansi untuk linearitas lebih kecil dari 0,05 ( $\mathrm{p}<0,05)$ sehingga dikatakan bahwa hubungan antara variabel regulasi diri dan variabel perencanaan karir telah menunjukkan adanya garis yang sejajar atau lurus.

Berdasarkan uji normalitas dan uji linieritas yang merupakan syarat untuk dapat melakukan uji hipotesis yang menggunakan metode analisis statistik product moment diperoleh hasil bahwa sebaran data bersifat normal dan hubungan kedua variabel yakni variabel regulasi diri dengan perencanaan karir adalah linear, sehingga analisis product moment yang digunakan untuk menguji korelasi varibel penelitian dapat dilalakukan. Hasil uji korelasi dapat dilihat pada tabel berikut:

Tabel 3

Hasil Uji Korelasi

\begin{tabular}{llcc}
\hline & \multicolumn{2}{c}{ regulasidiri } & perencanaankarir \\
\hline regulasidiri & Pearson Correlation & 1 & $.595^{* *}$ \\
& Sig. (1-tailed) & & .000 \\
& $\mathrm{~N}$ & 135 & 135 \\
perencanaankarir & Pearson Correlation & $.595^{* *}$ & 1 \\
& Sig. (1-tailed) & .000 & \\
& $\mathrm{~N}$ & 135 & 135 \\
\hline
\end{tabular}

Melalui hasil pengolahan secara komputasi tersebut diperoleh nilai koefisien korelasi (r) sebesar 0,595. Angka korelasi yang diperoleh sebesar (+) 0,595 yang menunjukkan bahwa adanya hubungan antara variabel regulasi diri dan variabel perencanaan karir. Tanda positif (+) menunjukkan bahwa semakin tinggi regulasi diri maka semakin tinggi atau baik pula perencanaan karir yang dilakukan . Hal ini memiliki arti bahwa kedua variabel memiliki hubungan atau saling berkorelasi.

Dalam analisis korelasi terdapat suatu angka yang disebut dengan koefisien determinasi (r2) diperoleh dengan mengkuadratkan nilai $r(0,595)$ sehingga didapatkan hasil $r 2$ sebesar 0,354. Koefisien determinasi menunjukkan besarnya peran atau sumbangan yang dapat diberikan dari variabel bebas terhadap variabel tergantung (Sugiyono, 2012). Berdasarkan koefisien determinasi sebesar 0,354, diperoleh sumbangan dari variabel regulasi diri terhadap variabel perencanaan karir dalam persen sebesar 35,4\%. Sedangkan sumbangan selain dari variabel regulasi diri terhadap variabel perencanaan karir adalah sebesar 64,6\%, yang diperoleh dari faktor-faktor lain, yang tidak diteliti dalam penelitian ini.

Peneliti juga melakukan penambahan analisa data dengan mencantumkan deskripsi data penelitian dan melalukan kategori skor skala untuk mengetahui subjek yang ada pada skor tertinggi dan terendah. Tujuan dari penggolongan ini adalah untuk menempatkan subjek ke dalam kelompok yang terpisah secara berjenjang menurut kontinum berdasarkan atribut yang diukur (Azwar, 2001)

Tabel 4

\begin{tabular}{cccccccc}
\multicolumn{7}{c}{ Deskripsi Data Penelitian } & \\
\hline Variabel & $\mathrm{N}$ & Mean & SD & X Max & X Min & $\begin{array}{c}\text { Mean } \\
\text { Teoritis }\end{array}$ & $\begin{array}{c}\text { Mean } \\
\text { Empiris }\end{array}$ \\
\hline Regulasi diri & 135 & 130.99 & 11.333 & 150 & 82 & 105 & 130.99 \\
$\begin{array}{c}\text { Perencanaan } \\
\text { Karir }\end{array}$ & 135 & 86.29 & 9.713 & 109 & 53 & 72,5 & 86.29 \\
\hline
\end{tabular}

Berdasarkan data yang telah dianalisis untuk variabel regulasi diri didapatkan hasil mean teoritis sebesar 105 yang lebih kecil daripada mean empiris yang sebesar 130,99. Hal ini menunjukkan bahwa rata-rata subjek dalam penelitian ini memiliki tingkat regulasi yang cukup tinggi. Pada variabel perencanaan karir diperoleh mean teoritis sebesar 72,5 yang lebih kecil daripada mean empiris yakni sebesar 86,29. Hal ini menunjukkan bahwa rata-rata subjek dalam penelitian ini memiliki tingkat perencanaan karir yang cukup tinggi.

Tabel 5

\begin{tabular}{llll|lllll}
\multicolumn{7}{c}{ Kategorisasi Skor Skala } \\
\hline \multicolumn{7}{c}{ Regulasi Diri } \\
\hline Rentang Nilai & Kategori & Subjek & $(\%)$ & Rentang Nilai & Kategori & Subjek & $(\%)$ \\
\hline $\mathrm{X} \leq 73,5$ & Sangat & 0 org & $0 \%$ & $\mathrm{X} \leq 50,75$ & Sangat & 0 org & $0 \%$ \\
& Rendah & & & & Rendah & & \\
$73,5 \leq \mathrm{X} \leq 94,5$ & Rendah & 2 org & $1 \%$ & $50,75 \leq \mathrm{X} \leq 65,25$ & Rendah & 2 org & $1 \%$ \\
$94,5 \leq \mathrm{X} \leq 115,5$ & Sedang & 8 org & $6 \%$ & $65,25 \leq \mathrm{X} \leq 79,75$ & Sedang & 28 org & $21 \%$ \\
$115,5 \leq \mathrm{X} \leq 136,5$ & Tinggi & 86 org & $64 \%$ & $79,75 \leq \mathrm{X} \leq 94,25$ & Tinggi & 72 org & $53 \%$ \\
$136,5<\mathrm{X}$ & Sangat & 39 org & $29 \%$ & $94,25<\mathrm{X}$ & Sangat & 33 org & $25 \%$ \\
& Tinggi & & & & Tinggi & & \\
\hline Jumlah & & 135 org & $100 \%$ & Jumlah & & 135 org & $100 \%$ \\
\hline
\end{tabular}

Analisis kategorisasi pada skala perencanaan karir menunjukkan bahwa subjek yang termasuk dalam kategori sangat tinggi ada $25 \%$, kategori tinggi ada $53 \%$, kategori sedang ada $21 \%$ dan kategori rendah ada $1 \%$. Melalui tabel diatas, berarti 33 orang masuk dalam kategori sangat tinggi, 72 orang masuk dalam kategori tinggi, 28 orang masuk dalam kategori sedang dan terdapat 2 orang yang masuk dalam kategori perencanaan karir yang rendah. 
Analisis kategorisasi pada skala regulasi diri menunjukkan bahwa subjek yang termasuk dalam kategori sangat tinggi ada $29 \%$, kategori tinggi ada $64 \%$, kategori sedang ada $6 \%$ dan kategori rendah ada $1 \%$. Berdasarkan tabel diatas, berarti 39 orang masuk dalam kategori sangat tinggi, 86 orang masuk dalam kategori tinggi, 8 orang masuk dalam ketegori sedang dan 2 orang termasuk dalam kategori rendah.

\section{PEMBAHASAN}

Dalam penelitian ini dilakukan pengujian hipotesis dari peneliti yang berbunyi terdapat hubungan yang positif antara regulasi diri dengan perencanaan karir remaja putri Bali. Untuk menguji hipotesis tersebut, peneliti melakukan analisa terhadap data melalui analisis statistik dengan menggunakan teknik korelasi product moment dari Karl Pearson.

Melalui analisis tersebut diperoleh hasil berupa koefisien korelasi (r) antara variabel regulasi diri dan variabel perencanaan karir sebesar 0,595 dan angka probabilitas yang didapat sebesar $0,000(\mathrm{p}<0,05)$ yang berarti bahwa kedua variabel tersebut saling berkorelasi positif secara signifikan, artinya jika terjadi peningkatan pada variabel regulasi diri maka akan terjadi peningkatan juga terhadap variabel perencanaan karir. Hasil penelitian tersebut sejalan dengan hasil penelitian dari Whitcomb (dalam Santrock, 2007) dimana dalam menentukan pilihan karir seorang remaja harus dapat melakukan perencanaan karir yang baik yang diawali dengan pengaturan diri yang tepat. Pengaturan diri atau regulasi diri tersebut berfungsi bagi para remaja agar dapat menikmati setiap pengalamannya menjadi seorang remaja seperti menjadi bagian dari teman sebaya, mengenyam pendidikan, memahami kebudayaan dan memilih karirnya.

Seorang remaja yang memiliki tingkat regulasi yang matang akan dapat memiliki penerimaan informasi yang baik, yakni dapat menerima informasi dari berbagai sumber yang diiringi dengan pengolahan sumber informasi yang ia terima, dapat melakukau evaluasi terhadap informasi yang diterima dengan norma- norma yang ia anut dalam lingkungannya, berani membuat suatu perubahan untuk kemajuan dirinya, mampu menemukan solusi terhadap permasalahan yang dihadapi, mampu merancang suatu rencana, baik dalam keseharian begitu juga merancang hal-hal yang terkait dengan masa depan mereka, tidak hanya sebatas pada merancang akan tetapi juga dapat menerapkan setiap rencana yang ia rancang ketika menentukan sebuah tujuan dan dapat melakukan pengukuran terhadap efektivitas dari rencana yang diterapkan Miller \& Brown ( dalam Neal \& Carey, 2005). Ketika pengaturan tersebut dapat dilakukan oleh seorang remaja ia akan dapat melakukan beberapa aktivitas dalam kesehariannya (Neal \& Carey, 2005). Maka dari itu apabila telah melatih diri untuk memiliki regulasi diri yang tepat, meskipun seorang remaja ada pada suatu keadaan yang membuat mereka harus terlibat dalam tugas perkembangan yang cukup kompleks seperti tuntutan dalam budayanya, seharusnya tidak menjadi beban untuk melakukan persiapan karir demi masa depannya. Dalam penelitian ini dapat diketahui nilai koefisien determinasi (r2) sebesar 0,354, nilai ini memiliki arti bahwa sumbangan variabel regulasi diri terhadap variabel perencanaan karir remaja putri Bali yaitu sebesar 35,4\%. Sedangkan $64,6 \%$ dipengaruhi oleh faktor lain di luar variabel regulasi diri.

Menurut Winkel \& Hastuti (2007), dalam sebuah perencanaan karir yang sukses, keberadaan diri sendiri merupakan faktor utama, karena dalam perencanaan karir diperlukan pengaturan dalam pengelolaan potensi diri serta informasi yang diperoleh. Selain itu, keberadaan faktor-faktor luar seperti keluarga, teman sebaya, budaya, sekolah pada akhirnya akan kembali kepada pengaturan diri untuk menentukan suatu pilihan karir. Santrock (2007) menyatakan bahwa, dalam merencanakan karir seorang remaja sangat tergantung dengan keadaan keluarga, pendidikan dan budayanya. Hal tersebut terjadi terutama bagi remaja putri yang biasanya sangat memperhatikan perannya dalam lingkungan sosial budaya yang mempengarahui struktur dan peluang mereka untuk menentukkan masa depan. Berdasarkan penelitian Gore \& Mets (2005) yang melihat tentang tingkat pendidikan terhadap kesuksesan seseorang untuk mencapai karirnya, hasil yang diperoleh adalah terdapat hubungan yang positif antara pendidikan yang tinggi dengan kesuksesan karir individu, yakni semakin tinggi pendidikan seseorang semakin sukses seseorang tersebut mencapai karir yang ia inginkan. Orang tua juga memiliki pengaruh yang sangat kuat terhadap pilihan karir remaja (Santrock, 2007). Peran dan pengaruh orang tua akan menjadi pengalaman tersendiri bagi seorang remaja dalam merencanakan karirnya.

Keberadaan budaya yang mempengaruhi remaja dalam menjalankan tugas perkembangan tentunya akan berbeda antar satu budaya dengan budaya yang lainnya (Sarwono, 2011). Terkait dengan tugas perkembangan dalam melakukan pilihan karir, menurut Seligman (2001) budaya akan mempengaruhi seorang remaja dalam menentukan keputusan karirnya, dimana keputusan tersebut dapat memiliki dampak yang positif dan negatif yang sangat tergantung dari dukungan orang- orang terdekatnya dan pengaturan diri yang dilakukan. Selain regulasi diri yang merupakan faktor internal dalam menentukan perencanaan karir, konsep diri yang dimiliki seorang remaja juga berperan dalam membuat perencanaan karir. Super (dalam Santrock 2007) berpendapat bahwa konsep diri individu berperan penting dalam pemilihan karir individu. Remaja yang memiliki konsep diri yang positif akan lebih mudah dalam melakukan perencanaan karir dibandingakan remaja yang terbentuk dengan konsep diri yang negatif. Maka dari itu penting bagi seorang remaja untuk dapat membangun konsep diri yang positif. 
Pada deskripsi data penelitian tampak bahwa pada variabel regulasi diri diperoleh mean teoritis sebesar 105 dan mean empiris sebesar 130,99. Hal ini menunjukkan bahwa rata-rata subjek dalam penelitian ini memiliki tingkat regulasi diri yang tinggi (mean teoritis < mean empiris). Demikian juga untuk variabel perencanaan karir, mean teoritisnya 72,5 dan mean empirisnya 86,29 sehingga dapat disimpulkan bahwa rata-rata subjek dalam penelitian ini memiliki perencanaan karir yang tinggi pula (mean teoritis < mean empiris). Melalui uraian hasil deskripsi data penelitian, tampak bahwa subjek dalam penelitian ini memiliki regulasi diri dan perencanaan karir yang tinggi.

Dari hasil kategorisasi pada skala regulasi diri menunjukkan bahwa subjek yang termasuk dalam kategori sangat tinggi ada 39 orang (29\%), kategori tinggi ada 86 orang (64\%), kategori sedang ada 8 orang ( $6 \%$ ) dan kategori rendah ada 2 orang (1\%). Secara keseluruhan dapat disimpulkan bahwa remaja Putri Bali yang menjadi subjek dalam penelitian ini memiliki tingkat regulasi yang tinggi. Kategorisasi skor subjek pada skala perencanaan karir subjek yang termasuk dalam kategori sangat tinggi ada 33 orang (25 $\%$ ), kategori tinggi ada 72 orang (53\%), kategori sedang ada 28 orang $(21 \%)$ dan kategori rendah ada 2 orang ( $1 \%)$. Hal ini menunjukkan bahwa remaja putri Bali yang menjadi subjek dalam penelitian ini memiliki perencanaan karir yang tinggi. Teori Gizberg (dalam Santrock 2007) menyatakan bahwa ketika seseorang ada pada rentang usia 15 sampai 20 tahun yang termasuk dalam tahanpan tentative dan realistis harusnya sudah memiliki perencanaan karir yang baik untuk persiapan karirnya. Pernyataan tersebut sesuai dengan hasil penelitian yang diperoleh, dimana remaja putri Bali yang menjadi subjek dalam penelitian ini, yang berada pada rentang usia 15 sampai 20 tahun sebagian besar memiliki perencanaan karir yang tinggi. .

Dengan demikian, setelah melalui prosedur penelitian dan analisis data yang sesuai, penelitian ini telah mencapai tujuannya yaitu mampu mengetahui bahwa regulasi diri memiliki hubungan yang positif dengan perencanaan karir remaja putri Bali serta berhasil membuktikan hipotesis yang berbunyi terdapat hubungan yang positif antara regulasi diri dengan perencanaan karir remaja putri Bali.

\section{Kesimpulan}

Berdasarkan hasil analisa dan pembahasan maka dapat ditarik kesimpulan mengenai hasil penelitian, sebagai berikut :

1. Hipotesis dari penelitian ini adalah ada hubungan yang positif antara regulasi diri dengan perencanaan karir remaja putri Bali. Hasil penelitian menunjukkan bahwa terdapat hubungan positif yang signifikan antara regulasi diri dengan perencanaan karir remaja putri Bali, yang ditunjukkan dengan nilai korelasi sebesar (+) 0,595 dan angka probabilitas (p) 0,000. Makna dari hubungan positif adalah semakin tinggi regulasi diri maka semakin tinggi pula perencanaan karir yang dimiliki. Hal ini menunjukkan bahwa hipotesis penelitian dapat diterima.

2. Hasil penelitian menunjukkan hubungan yang signifikan dengan sumbangan yang diberikan variabel regulasi diri terhadap perencanaan karir yakni sebesar $35,4 \%$ dan sisanya sebesar $64,6 \%$ dipengaruhi oleh faktor- faktor lain yang tidak diteliti dalam penelitian ini.

3. Berdasarkan deskripsi data penelitian maka dapat disimpulkan 2 hal yaitu

a. Deskripsi data penelitian pada regulasi diri berada pada kategori tinggi. Hal ini menunjukkan bahwa sebagian besar subjek memiliki skor rata-rata pada kategori tinggi

b. Deskripsi data penelitian pada perencanaan karir berada pada kategori tinggi. Hal ini menunjukkan bahwa sebagian besar subjek memiliki skor rata- rata pada kategori tinggi.

\section{Saran}

\section{Saran praktis}

a. Remaja hendaknya melatih diri agar dapat memiliki regulasi diri yang tepat terlebih bagi remaja putri Bali yang terlibat dalam peran sosial dan dalam tugas perkembangan remaja yang lainnya. Terdapat beberapa cara bagi remaja putri untuk melatih regulasi diri seperti, membiasakan diri untuk membuat jadwal kegiatan sehari- hari, memiliki catatan kecil yang berfungsi untuk mencatat kegiatan- kegiatan yang akan dilakukan diluar dari jadwal kegiatan sehari- hari, dan belajar menentukan skala prioritas sehingga dapat melakukan pengambilan keputusan yang tepat.

b. Dalam melakukan perencanaan karir, sangat penting bagi remaja untuk melakukan pengaturan terhadap potensi diri dan informasi yang diperoleh, maka dari itu regulasi diri hendaknya diterapkan dalam perencanaan karir dan tugas perkembangan lainnya sehingga remaja dapat melakukan setiap tugas perkembangannya dengan baik khususnya dalam merencanakan karir untuk dapat menentukan pilihan karir yang tepat. Penerapan proses regulasi diri dalam perencanaan karir seperti : mencari informasi terhadap hal- hal yang diminati remaja, melakukan evaluasi, membandingkan dengan keadaan diri sendiri dan lingkungan, menyiapkan solusi, memformulakan solusi, menerapkan rencana terkait dengan keputusan yang diambil dan melalakukan pengukuran kembali terhadap keputusan tersebut.

c. Bagi organisasi kepemudaan di Bali yakni sekaa teruna, selain berperan dalam kegiatan adat dan budaya, hendaknya dalam program kegiatan menambahkan program yang berkaitan dengan kemajuan karir para anggotanya. Kegiatan tersebut dapat dimasukkan dalam program pengembangan aktivitas sekaa teruna . Beberapa kegiatan 
yang dapat direncanakan meliputi, seminar tentang perencanaan karir dengan mengundang professional yang ahli dalam karir, selain itu juga dapat mengundang tokoh-tokoh masyarakat yang merupakan mantan anggota sekaa teruna yang sudah sukses dalam mencapai karirnya. Dengan mengadakan kegiatan tersebut anggota sekaa teruna ditengah aktivitas pendidikan dan perannya dalam kegiatan budaya akan mendapatkan paradigma baru tentang karir untuk kemajuan masa depan mereka. Kegiatan lain yang dapat dilakukan seperti dream sharing. Dream sharing adalah kegiatan diskusi santai bagi seluruh anggota sekaa teruna yang didalamnya menceritakan impian- impiannya yang berhubungan dengan kemajuan masa depannya.

\section{Saran bagi peneliti selanjutnya}

a. Mengacu pada nilai koefisien determinasi sebesar 0,354 yang berarti bahwa sumbangan yang diberikan oleh variabel regulasi diri terhadap perencanaan karir yaitu sebesar $35,4 \%$ dan selebihnya sebesar $64,6 \%$ dipengaruhi oleh faktor lain yang tidak diteliti dalam penelitian ini. Maka disarankan kepada peneliti selanjutnya yang meneliti topik yang berhubungan dengan regulasi diri dan perencanaan karir agar mengkaji faktor- faktor lain seperti, konsep diri, orang tua, pendidikan, motivasi dan lingkungan sosial budaya.

b. Dari hasil uji coba skala penelitian, pada skala regulasi diri terdapat 21 item yang gugur. Jumlah item yang gugur pada skala regulasi diri cukup banyak yakni dari 63 item hanya tersisa 42 item. Banyakya item yang gugur dapat disebabkan oleh faktor eksternal seperti subjek yang tidak sungguh- sungguh dalam mengisi kuisioner atau dari faktor internal yakni pemilihan konstruk yang digunakan sebagai dasar dalam pembuatan kuisioner tidak benar- benar dapat mengukur tujuan penelitian. Maka dari itu untuk penelitian selanjutnya hendaknya lebih memperhatikan dan memeriksa dengan lebih detail terkait alat ukur yang akan digunakan dalam penelitian yang berhubungan dengan regulasi diri, selain itu juga dapat memberikan pengawasan ketika subjek mengisi kuisioner penelitian.

c. Berdasarkan hasil dari kategorisasi subjek pada skala regulasi diri, sebanyak $6 \%$ ada pada kategori sedang, $64 \%$ subjek ada pada kategori tinggi dan $29 \%$ ada pada kategori sangat tinggi. Sedangkan pada perencanaan karir kategori sedang sebanyak 21\%, kategori tinggi sebanyak $53 \%$ dan sebanyak $25 \%$ ada pada kategori sangat tinggi. Hasil tersebut jika disesuaikan dengan hasil korelasi yakni jika subjek dalam penelitian memiliki tingkat regulasi diri yang tinggi juga akan diikuti dengan tingginya tingkat perencanaan karir, tidak terpenuhi oleh semua subjek dalam hasil kategorisasi subjek. Hal ini dapat dilihat dari adanya perbedaan jumlah subjek pada kategorisasi tinggi dan sangat tinggi pada regulasi diri dengan perencanaan karir. Perbedaan tersebut tidak begitu signifikan akan tetapi tetap menjadi keterbatasan dalam penelitian ini karena hal tersebut belum dapat diketahui penyebabnya. Oleh sebab itu bagi peneliti selanjutnya dapat didilakukan pengkajian yang lebih mendalam untuk mengetahui penyebab terkait dengan perbedaan jumlah subjek pada kategori rata-rata tinggi pada skala regulasi diri dan skala perencanaan karir.

d. Berdasarkan banyaknya sampel yang digunakan dalam penelitian ini yaitu sebesar 135 subjek maka untuk penelitian selanjutnya agar memperbanyak jumlah sampel sehingga jawaban yang diperoleh lebih bervariasi dan dapat dilakukan generalisasi yang lebih akurat.

\section{DAFTAR PUSTAKA}

Alwisol. (2007). Psikologi Kepribadian. Malang : UMM Press.

Arjani, N. L. (2007). Feminisasi Kemiskinan dalam kultur Patriarki. Jurnal studi gender Srikandi Vol vii No 1 Denpasar .

Astiti, T. I. (2008). Perempuan Bali : Jalan berliku menuju politik praktis . Denpasar : Pustaka Bali post .

Azwar, S. (2010). Dasar Dasar Psikometri. Yogyakarta: Pustaka Pelajar.

Azwar, S. (2010). Metode Penelitian. Yogyakarta: Pustaka Belajar.

Azwar, S. (2010 ). Reliabilitas dan Validitas edisi ke 3. Yogyakarta : Pustaka Pelajar .

Azwar, S. (2000). Tes Prestasi : Fungsi dan Pengembangan Pengukuran Tes Prestasi Belajar. Yogyakarta: Pustaka Belajar .

Beuder. (2007, januari ). Career . Retrieved Maret Senin, 2012 , from bruderfic: http://bruderfic.or.id/h-62/perencanaan-karier-sejakdini.html

Boeree, C. G. (2004). Personality Theories melacak kepribadian anda bersama psikolog dunia. Jogjakarta: Prismasophi.

Budi, T. (2006 ). SPSS 13.0 Terapan: Riset Statistik Parametrik . Yogyakarta : Andi .

Burger, J. M. (2008 ). Personality seventh edition . USA: Wadsworth

BPS. (2010). Survey sosial ekonomi Nasional. Badung: Badung.

BPS. (2007, 2008). Suvey sosial ekonomi Nasional. Bali

Creed, P. A. (2011). The relationship between career adaptability, person and situation variables,. Career adaptability and career concerns , 1-30.

Ferdinand. (2006). Metode Penelitian Manajemen Badan Penerbit Universitas Diponegoro. Semarang .

George. D. (2010). Managing Human Resources. USA: Pearson.

George, D. (2009). strong feedback in organization. OB and Human Resource vol 1 management class , 28- 41.

Gerald, C. (2005). Theory and Practice of Counseling and Psychoterapy. USA: Thompson learning.

Hurlock, E. (2000). Psikologi Perkembangan : Suatu Pendekatan Sepanjang Rentang Kehidupan. Jakarta: Erlangga.

Hurlock, E. (2001). Psikologi Perkembangan. Edisi 5. Jakarta: Erlangga .

Irianto, J. (2003). Tema tema pokok manajemen sumber daya manusia. Surabaya : Insan Cendekia.

Masril. (2011). Konseling regulasi diri berbasis teori pilihan . Bimbingan \& Konseling UPI Bandung, 15- 35.

Matsumoto, D. (2008). Pengantar psikologi lintas budaya. yogyakarta: Pustaka belajar. 
Mayasari. (2009). Hubungan antara dukungan keluarga dengan prestasi. psik, 1-8.

Narbuko, C., \& Achmadi, H. (2004). Metodelogi Penelitian. Jakarta: PT Bumi Aksara.

Neal, D. \&. (2005). A Follow-Up Psychometri Analysis of the Self Regulation Questionare. Psychology journal : Psychology of Addictive Behaviour , 414-422.

Permatasari, R. (2012). Hubungan antara Good Coorporate Governance dengan kinerja keuangan pada perusahaan yang terdaftar dalam Indonesia Most Trusted Companies berdasarkan survei investor dan analis Periode 2008-2010. repository.upi.edu , 1-10.

Raditya, Utama . (2011). Bali Aneka Perspektif : Remaja Bali Budaya dan Masa Depan. Denpasar

Santrock, J. W. (2007). Remaja, jilid 2 edisi kesebelas. Jakarta: Erlangga.

Sarwono, S. W. (2011). Psikologi Remaja . Jakarta : Rajawali Pers .

Simamora, H. (2006). Manajemen sumber daya manusia. Yogyakarta : STIE YKPN .

Seligman, L. (2001). Developmental career counseling and assesment. Virginia: George Mason University.

Sri, D. G. (2012, Februari 3). Peran remaja putri dalam kegiatan adat dan perencanaan karir. (A. Istriyanti, Interviewer)

Suci, R. R. (2008). Perbedaan Self Regulation Pada Mahasiswa Yang Bekerja dan Mahasiswa yang Tidak Bekerja . Journal Psikologi Universitas Paramadina , 1-15.

Sugiyono. (2009). Metode Penelitian Kuantitatif, Kualitatif dan $R \&$ $D$. Bandung : Alfabeta .

Sugiyono. (2012). Statistika Untuk Penelitian. Bandung: alfabeta.

Suryabrata, S. (2000). Metodelogi Penelitian. Yogyakarta: Raja Grafindo Persada.

Taylor, S. E. (2009). Psikologi sosial. Jakarta: Kencana.

Utama, S. D. (2009). Ekalikita Sekaa Teruna Dwi Satya Utama. Badung, Bali : Desa Adat lambing Sibangkaja .

Wahana. (2009). SPSS 17 untuk pengolahan data statistik. Semarang: Andi.

Werdhi, S. (2009, September kamis ). Membangun sekaa Teruna . diakses February Minggu , 2012, dari : Sekaa teruna : membangun-sekaa-teruna.html

Winkel \& Sri Hastuti. (2007). Bimbingan dan konseling di industri pendidikan. Yogyakarta: Media abadi.

Wiranatha, A. S. (2005). Bali menuju jagadhita, aneka perspektif : Potret masa depan, prediksi, skenario dan rekomendasi pembangunan Bali. Denpasar: Pustaka Bali Post .

Zunker, V. G. (1986). Career Counseling: Applied Concepts of Life Planning. Second Edition. Chapter 2: Theories of Career Development. California: Cole Publishing Company. 